\title{
The Effects of Partial Chronic Denervation on Forearm Metabolism
}

\author{
GEORGE KARPATI, GERALD KLASSEN AND PAUL TANSER
}

SUMMARY: Effects of chronic denervation upon in vivo forearm metabolism were studied in six patients and six controls. The diagnosis w'as amyotrophic lateral sclerosis in four patients, the neuronal form of Charcot-Marie Tooth disease in one patient, and an unclassified chronic disease of the low'er motor neurons in one patient. In all cases the forearm muscles show'ed clinical weakness and electrical evidence of denervation, while muscle biopsy from a proximal muscle of the upper limb show'ed typical denervation atrophy. At rest there was increased oxygen utilization and lactate output as well as a tendency for increased uptake of

RÉSUMÉ: L'activité métabolique in vivo des tissus de l'avant-bras fut studié chez 6 patients porteurs d'attente du neurone moteur inférieur et comparée à 6 témoins normaux. Quatre malades étaient affligés de sclèrose laterale amyotrophique, un d'une forme axonale de Charcot-MarieTooth et un dernier d'une forme chronique non classifiée de maladie du neurone moteur inférieur. Tous les patients étudiés démontraient une faiblesse clinique des muscles de l'avant-bras, des signes electriques typiques de dénervation et à la biopsie musculaire d'un muscle proximal du membre supérieur une image typique d'atrophie neurogéne.

Au repos, par $100 \mathrm{ml}$ de tissue d'avantbras considéré, on notait une augmentation de la consommation d'oxygéne et de la glucose and long chain fatty acids from arterial blood per $100 \mathrm{ml}$ of forearm tissue. During exercise the abnormally high lactate output increased further. An increased arterial lactate concentration was present during rest and exercise. Oxidation of fatty acids was not impaired. It is suggested that these abnormalities are consistent with an augmented utilization of blood borne fuels at rest by denervated muscles. A concurrent regional ischemia of muscles during rest and exercise, possibly due to defective autoregulation of skeletal muscle blood flow, may exlain the abnormally high lactate generation.

production de lactate de même qu'une tendance à une captation accrue d'acides gras à longue chaine et de glucose artériels. A l'effort la production élévée de lactate observée qu repos s'accentuait d'avantage. Au repos comme à l'effort d'autre part, les concentrations arterielles systémiques de lactate étaient élevées et le metabolism des acides gras à longue chaine etait normal. Nous en concluons que ces anomalies suggèrent une consommation accrue des carburants hématogènes par les muscles denervés, au repos, et qu'au repos comme à l'effort, dans des circonstances d'ischémie régionale, la production supranormale de lactate puisse s'expliquer par une déficience de l'autorégulation circulatoire $d u$ muscle squelettique.

\section{INTRODUCTION}

The purpose of this study was to measure the metabolic responses of the forearm muscles of patients in whom a disease process had resulted in denervation. We hoped to learn which metabolic alterations occurred in the partially denervated muscles at rest, during, and following exercise. Muscle biopsies were performed to correlate structural changes with metabolic abnormalities. In order to facilitate interpretation of data, a group of normal subjects were studied at the same time using the same study protocol.

\section{METHODS}

Six patients with chronic denervating diseases were included in the study (Table 1). The diagnosis in four patients was amyotrophic lateral sclerosis in moderately advanced stage. One patient suffered from the neuronal form of Charcot-Marie Tooth disease, and one patient had an unclassified chronic disease of the spinal motor neurons. The diagnosis was based on clinical assessment, electromyography, and muscle (and in some patients peripheral nerve) biopsy. The forearm muscles in each patient showed moderate weakness and electromyographic evidence of denervating process. Every patient and control subject gave informed consent for participation in this study.

The controls were clinically normal hospital employees without past history of major illness. Biopsy of biceps brachii from these individuals revealed no histochemical abnormalities. Normal controls received financial remuneration. Muscle biopsy and the preparation of histochemical specimens were done according to the technique of
From the Montreal Neurological Institute (Dr. Karpati) and the Royal Victoria Hospital, Montreal (Drs. Klassen and Tanser).

Reprint requests to Dr. G. Karpati, Montreal Neurological Institute, 3801 University Street, Montreal, Quebec, H3A 2B4. Canada. 
TABLE I

Characteristics of patients with denervation (D) and ('ontrols (C)

\begin{tabular}{|c|c|c|c|c|c|c|c|}
\hline \multicolumn{2}{|c|}{ Diagnosis of patients } & \multicolumn{2}{|c|}{$D^{\text {Age }} \mathrm{C}$} & \multicolumn{2}{|c|}{${ }^{\text {Sex }} C$} & \multicolumn{2}{|c|}{$\underset{\text { D }}{\text { Forearm Volume* }}$ C } \\
\hline 1 & Amyotrophic Lateral Sclerosis & 45 & 49 & $\mathrm{~F}$ & $\mathrm{~F}$ & 475 & 1150 \\
\hline 2 & Lower Motor Neuron Disease & 40 & 58 & M & $\mathrm{F}$ & 1125 & 1000 \\
\hline 3 & Amyotrophic Lateral Sclerosis & 69 & 24 & $\mathrm{~F}$ & $\mathrm{~F}$ & 450 & 750 \\
\hline 4 & Amyotrophic Lateral Sclerosis & 72 & 53 & M & M & 750 & 950 \\
\hline \multirow[t]{2}{*}{5} & Neuronal form of & & & & & & \\
\hline & Charcot-Marie Tooth Disease & 27 & 29 & $\mathrm{~F}$ & M & 450 & 1200 \\
\hline \multirow[t]{3}{*}{6} & Amyotrophic Lateral Sclerosis & 50 & 45 & M & M & 1050 & 1200 \\
\hline & Mean & 51 & 43 & & & 717 & 1042 \\
\hline & \pm SEM & 7 & 6 & & & 126 & 72 \\
\hline
\end{tabular}

* Forearm volume was measured as $\mathrm{ml}$ by water displacement; the volume of the hand was excluded.

Dubowitz and Brooke (1973). The technique of forearm studies was similar to that published by Andres et al (1951) and Zierler et al. (1968). We have previously reported our applications of these methods and the results from such studies (Klassen et al., 1969, 1970). The experiments were performed in a constant temperature room, at 9:00 a.m. on fasting subjects. A soft plastic catheter was passed retrograde to flow from the antecubital vein into the forearm muscle bed so that its tip could not be felt (corresponding to Zierler's "deep venous site"). The catheter was kept patent with a slow physiological saline infusion. A double lumen arterial needle was inserted retrograde to flow into the cubital artery which permitted sampling of distal arterial blood while indicators were infused proximally. Local analgesia for needle insertion was obtained with $2 \%$ Lidocaine. Indicators which were infused by a servo-regulated constant speed pump consisted of Evans blue $\left(\mathrm{T}_{1824}\right)$ to measure plasma flow and $\mathrm{C}^{14}$ labelled oleic acid* bound to albumin. Additional carrier albumin was added to the injectate to minimize the loss of indicator by adherence onto tubing.

\footnotetext{
*The binding and sterility testing of this indicator was performed by Merck Company, Montreal. It was subsequently tested by radiochromatography and found to be $>99 \%$ labelled oleic acid.
}

\section{EXPERIMENTAL PROCEDURES:}

After all cannulas had been placed, the infusion of indicator was started so as to allow an equilibration period of 30 minutes. Two sets of arterial and venous blood were drawn over the next 30 minutes ("rest" samples). Five minutes before sampling, a pneumatic cuff was inflated to slightly greater than the arterial pressure at the wrist in order to exclude the hand from the circulation during the measurement period. Five minutes before exercise was started, the cuff was reinflated in the same manner and remained inflated for the duration of exercise ( 15 minutes). Exercise was timed with a metronome and consisted of active and maximal flexion and extension of the hand at the wrist over an arc of about 90 degrees (with the arm in the midpronation position) at a rate of one cycle per second. This exercise program ensured active muscle contraction involving a large portion of the forearm musculature against a standard load (gravity). Some patients experienced subjective fatigue during exercise and had to be encouraged, but without compromising the amount of active work done. This exercise did not involve the small muscles of the hand so ischemic hand pain was avoided. At 4,8 , and 12 minutes from the start of exercise, simultaneous arterial and venous blood samples were taken
("Exercise" samples). The cuff was then released. Thirty and fifty minutes after the start of exercise, two sample sets were obtained which constituted the "recovery" samples.

\section{SAMPLE HANDLING:}

Blood was drawn into syringes which had their dead space filled with heparin. The blood was immediately processed by preparing protein free filtrate using barium sulfate and zinc hydroxide. All syringes were calibrated and the dilution with heparin was corrected. Hematrocrit was measured from a mixed sample. The remaining blood was chilled on ice and then centrifuged in a refrigerated centrifuge. Samples of plasma were then rapidly frozen for further processing. All analytical procedures and standards were measured in triplicate and final results calculated using a Fortran program. Statistical analysis of data was according to the methods of Snedecor and Cochran (1967).

\section{ANALYTICAL METHODS:}

Blood flow was measured by constant infusion of Evans blue dye: the dilution in plasma was determined by spectrophotometer. Oxygen and carbon dioxide content were measured by the method of Van Slyke and Neill (1924). $\mathrm{pH}, \quad \mathrm{pCO}_{2}$ and $\mathrm{pO}_{2}$ were measured using an IL electrode system. Plasma creatinine phosphokinase (CPK) activity was measured according to the methods of Kuby et al. (1954), as adopted for the Sigma Kit 40-UV.* Potassium was measured by flame photometry using internal standards and calcium by an atomic absorption spectrometer. Glucose was measured in the protein free filtrate using glucose oxidase (McCann and Jude, 1958) and the concentration of lactate was determined by a lactate dehydrogenase technique (Horn and Bruns, 1956). Plasma oleic acid concentration was measured using an internal standard (heptadecanoic acid) and gas liquid chromatography as previously described (Klassen, 1974). Less than one microcurie of radioactivity was infused during the study. For the calculation of data we used the 


\section{Forearm Blood Flow During Rest, Exercise and Recovery in Patients and Controls}

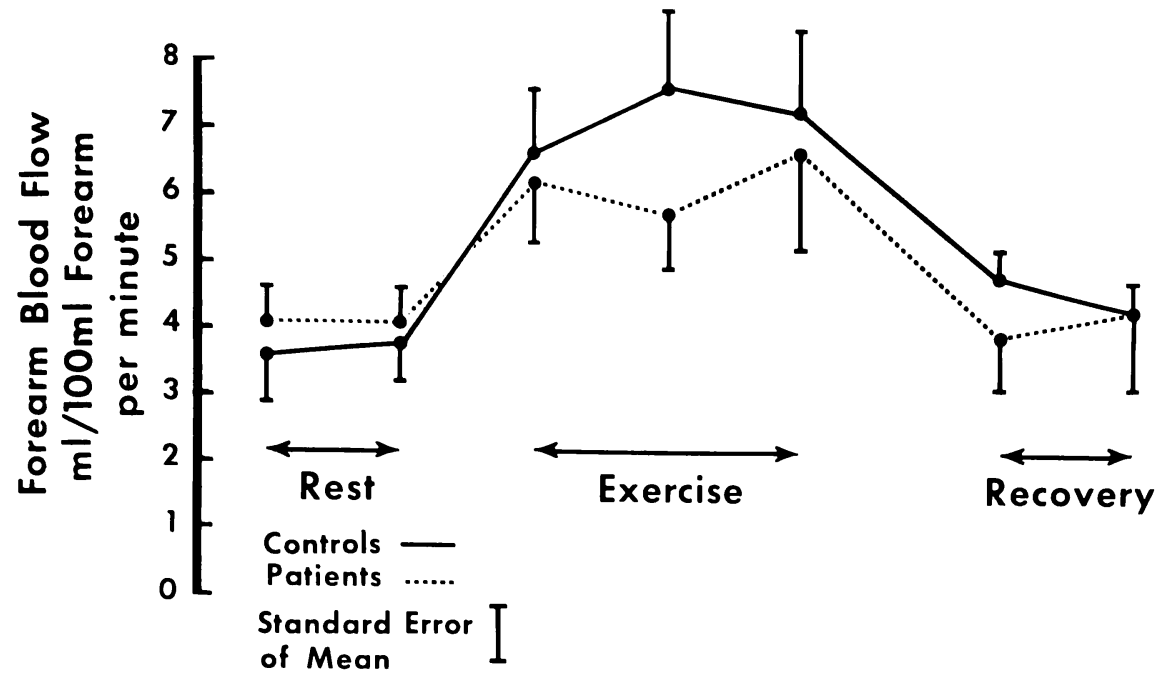

Fig. $I=$ - Forearm blood flow during rest, exercise, and recovery in patients and controls. formulas derived by Zierler (1968) for the analysis of forearm data.

*Sigma Chemical Company, St. Louis, Mo., USA.

\section{RESULTS}

(All results are expressed as means \pm standard error of the mean)

The normal subjects were able to perform the exercise without difficulty. Three of the patients had considerable evidence of muscle wasting as indicated by the decreased forearm volume (Table 1).

\section{Blood Flow (Figure 1)}

Total forearm blood flow was normal at rest in both groups and similar to that reported by Baltzan et al. (1962) in resting normals $(3.71 \pm$ $.017 \mathrm{ml} / 100 \mathrm{ml}$ forearm $/ \mathrm{min}$ ). It increased significantly during exercise in both groups and then returned to resting levels during the recovery period.

\section{Oxygen and Carbon Dioxide Metabolism (Table 2)}

Arterial oxygen and carbon dioxide content remained constant during the procedure. The oxygen content was slightly lower in denervated subjects, presumably reflecting a lower hematocrit (normals $0.39 \pm .01$ compared to denervated $0.36 \pm .02$ ) since the arterial $\mathrm{p}_{2}$ was similar. The seemingly low hematocrit in controls is in keeping with earlier results (Baltzan et al, 1965) and may be related to the fact that the venous return was not occluded when the specimens were taken. Carbon dioxide content was higher in patients, reflecting a higher arterial $\mathrm{pCO}_{2}$.

Forearm oxygen consumption in controls (flow $X$ arteriovenous difference) was $7.98 \pm 1.12 \mathrm{um} / 100 \mathrm{ml}$ forearm $/ \mathrm{min}$ at rest, increased to $31.89 \pm 6.10$ during exercise, and returned to $12.68 \pm 2.85$ on recovery. The similar values in patients were $13.25 \pm 3.70$ at rest, $20.39 \pm 3.11$ during exercise, and $14.47 \pm 3.84$ on recovery. The increase at rest in the patients was significant $(\mathrm{p}<.05)$. Although during exercise the oxygen consumption was reduced in denervated patients, the difference was not significant. Recovery oxygen consumption again tended to be higher in patients.

Carbon dioxide production tended to parallel oxygen consumption. During exercise normals produced $27.63 \pm 5.66 \mathrm{uM} / 100 \mathrm{ml}$ forearm $/ \mathrm{min}$ of $\mathrm{CO}_{2}$, while patients produced $12.56 \pm 2.90$; the difference in this response was significant $(p<.05)$.

Respiratory quotient increased somewhat during exercise in either
TABLE 2

Blood gas content in controls (C) and patients (D)

\begin{tabular}{cccc}
\hline & Rest & Exercise & Recovery \\
\hline & & Arterial Oxygen Content $(\mu \mathbf{M} / \mathbf{m l})$ \\
C & $7.34 \pm 0.15$ & $7.36 \pm 0.33$ & $7.54 \pm 0.26$ \\
D & $6.89 \pm 0.39$ & $6.63 \pm 0.32$ & $6.85 \pm 0.66$ \\
\hline \multicolumn{3}{c}{ Arteriovenous Oxygen Differences $(\mu \mathbf{M} / \mathbf{m l})$} \\
C & $2.24 \pm 0.33$ & $4.15 \pm 0.44$ & $2.62 \pm 0.42$ \\
D & $3.17 \pm 0.59$ & $3.58 \pm 0.34$ & $3.13 \pm 0.81$ \\
\hline
\end{tabular}

Arterial Carbon Dioxide Content $(\mu \mathrm{M} / \mathrm{ml})$

$\begin{array}{llll}\text { C } & 21.14 \pm 0.59 & 20.80 \pm 0.50 & 20.74 \pm 0.43 \\ \text { D } & 23.61 \pm 1.00 & 23.85 \pm 1.10 & 24.58 \pm 1.50\end{array}$

\begin{tabular}{llcr} 
& \multicolumn{3}{c}{ Arteriovenous Carbon Dioxide Difference $(\mu \mathbf{M} / \mathbf{m l})$} \\
C & $-1.53 \pm 0.11$ & $-3.48 \pm 0.19$ & $-1.56 \pm 0.21$ \\
$D$ & $-1.97 \pm 0.42$ & $-2.15 \pm 0.40$ & $-1.69 \pm 0.33$
\end{tabular}

\begin{tabular}{llcl}
\hline & & Respiratory Quotient & \\
$\mathrm{C}$ & $76 \pm 13$ & $88 \pm 13$ & $60 \pm 9$ \\
$\mathrm{D}$ & $64 \pm 8$ & $59 \pm 8$ & $56 \pm 9$ \\
\hline
\end{tabular}

Results are expressed as means \pm standard error of the mean Statistical analysis of data revealed no significant differences. 
group but tended to be lower in denervated patients. In all instances the RQ values suggest fatty acids as a major metabolic fuel during the course of the study in agreement with the observations of others (Baltzan et al, 1962; Felig and Wahren, 1975).

\section{$p \mathrm{H}, \mathrm{pCO} \mathrm{O}_{2}$ and $\mathrm{pO}_{2}$ (Table 3)}

All of the arterial values of $\mathrm{O}_{2}$ and $\mathrm{CO}_{2}$ partial pressures were within the accepted normal range. At rest there was a tendency $(p<.05)$ for the venous $\mathrm{pO}_{2}$ to be lower and the $\mathrm{pCO}_{2}$ higher in the patients than in the controls. This difference disappeared during exercise but was again present during recovery.

These observations suggest that at rest or during recovery a slight increase in oxidative metabolism may be present in denervation as reflected by an increased oxygen consumption. The exercise responses were probably appropriate.

\section{Serum Creatine Kinase (Table 3)}

$\therefore$ Creatine phosphokinase (CPK) activity was significantly increased in the patients sera throughout the experiments. The arterial and venous activity CPK was similar, implying that denervation did not seem to alter the flux of these enzymes during exercise.

\section{Potassium (Table 4)}

Arterial potassium concentration was in the normal range for both groups and did not change with exercise or recovery. At rest we observed net potassium output in both groups, which is probably a reflection of higher cortisol levels in the morning (Andres et al, 1954). Exercise stimulated an increase in potassium loss from muscle which was similar to results previously reported in normal subjects. The exercise induced output of potassium was less in the denervated patients than normal controls but it was not significant. During recovery both groups showed comparable potassium uptake by muscle. The decreased potassium output observed with exercise in denervated patients was probably due to less vigorous exercise.

\section{Calcium (Table 4)}

Arterial calcium concentrations were within the normal range in both groups. Klassen et al (1970) previously reported net calcium output during similar exercise in athletes. The normals in this study had only minimal output during exercise followed by uptake during recovery. Denervated patients tended to have uptake throughout the study. These differences may be a reflection of the degree and nature of forearm muscle activity prior to the disease.

\section{Glucose (Table 5)}

Arterial glucose concentration was constant during the procedure and was within the normal range in both groups. As in a previous report (Klassen et al, 1970), arteriovenous differences did not change with exercise or recovery in either group. There was a trend for arteriovenous differences to be wider in the denervated patients.

We calculated the percent of the oxygen consumption which could be attributed to glucose oxidation,

TABLE 3

$p H, p \mathrm{CO}_{2}, \mathrm{pO}_{2}$ and serum $\mathrm{CPK}$ in arterial and deep venous blood at rest during exercise, and recovery in controls (C) and patients (D)

\begin{tabular}{|c|c|c|c|c|c|c|}
\hline & \multicolumn{2}{|c|}{ Rest } & \multicolumn{2}{|c|}{ Exercise } & \multicolumn{2}{|c|}{ Recovery } \\
\hline & Arterial & Venous & Arterial & Venous & Arterial & Venous \\
\hline $\begin{array}{l}\text { C } \\
\text { D }\end{array}$ & $\begin{array}{l}7.42 \pm .01 \\
7.45 \pm .02\end{array}$ & $\begin{array}{l}7.39 \pm .01 \\
7.41 \pm .02\end{array}$ & $\begin{array}{l}7.42 \pm .01 \\
7.44 \pm .02\end{array}$ & $\begin{array}{l}7.38 \pm .01 \\
7.39 \pm .02\end{array}$ & $\begin{array}{l}7.42 \pm .01 \\
7.46 \pm .02\end{array}$ & $\begin{array}{l}7.40 \pm .01 \\
7.42 \pm .02\end{array}$ \\
\hline $\begin{array}{l}\text { C } \\
\text { D }\end{array}$ & $\begin{array}{l}36.9 \pm 1.6 \\
39.4 \pm 1.2\end{array}$ & $\begin{array}{r}40.5 \pm 1.8 \\
45.8 \pm 1.0 \\
p<.05\end{array}$ & $\begin{array}{l}36.6 \pm 1.3 \\
39.9 \pm 1.4\end{array}$ & $\begin{array}{l}\text { g) } \\
44.4 \pm 2.7 \\
46.9 \pm 1.3\end{array}$ & $\begin{array}{l}37.2 \pm 1.8 \\
37.9 \pm 0.8\end{array}$ & $\begin{array}{r}41.7 \pm 2.3 \\
44.7 \pm 2.3 \\
p<.05\end{array}$ \\
\hline $\begin{array}{l}\text { C } \\
\text { D }\end{array}$ & $\begin{array}{l}77.1 \pm 2.4 \\
78.8 \pm 3.8\end{array}$ & $\begin{array}{r}37.0 \pm 1.8 \\
28.5 \pm 4.5 \\
p<.05\end{array}$ & $\begin{array}{l}79.2 \pm 2.8 \\
78.4 \pm 6.3\end{array}$ & $\begin{array}{l}24.9 \pm 1.6 \\
24.6 \pm 4.9\end{array}$ & $\begin{array}{l}76.6 \pm 3.9 \\
79.3 \pm 3.7\end{array}$ & $\begin{array}{r}35.4 \pm 1.8 \\
26.2 \pm 3.5 \\
\mathrm{p}<.05\end{array}$ \\
\hline $\begin{array}{l}\text { C } \\
\text { D }\end{array}$ & $\begin{array}{c}6.9 \pm 1.6 \\
20.5 \pm 13.0 \\
p<.05\end{array}$ & $\begin{array}{c}7.4 \pm 1.8 \\
23.6 \pm 16.6 \\
p<.05\end{array}$ & $\begin{aligned} & \mathbf{C P K} \\
& 5.2 \pm 1.6 \\
& 21.2 \pm 13.0 \\
& \mathrm{p}<.05\end{aligned}$ & $\begin{array}{l}\text { nits) } \\
4.8 \pm 1.1 \\
17.1 \pm 11.0 \\
\text { p }<.05\end{array}$ & $\begin{array}{c}5.3 \pm 1.2 \\
26.2 \pm 11.7 \\
\mathrm{p}<.02\end{array}$ & $\begin{array}{c}5.1 \pm 1.7 \\
33.8 \pm 15.1 \\
\mathrm{p}<.02\end{array}$ \\
\hline
\end{tabular}

Results are expressed as means \pm standard error of the mean.

Statistical analysis of data revealed significant differences only in serum $\mathrm{CPK}$ activity, venous p0 and pC $0_{2}$ during rest and post-recovery.

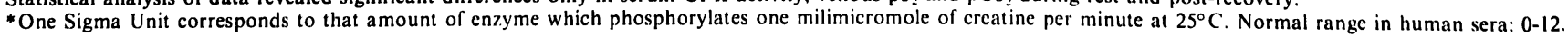


TABLE 4

Arterial concentrations and arteriovenous differences of electrolytes in controls (C) and patients (D)

\begin{tabular}{|c|c|c|c|c|c|c|c|}
\hline & \multicolumn{2}{|c|}{ Rest } & \multicolumn{3}{|c|}{ Exercise } & \multicolumn{2}{|c|}{ Recovery } \\
\hline \multirow{3}{*}{$\begin{array}{l}\text { C } \\
\text { D }\end{array}$} & \multirow{3}{*}{$\begin{array}{l}4.10 \pm 0.10 \\
4.07 \pm 0.20\end{array}$} & \multirow{3}{*}{$\begin{array}{l}4.06 \pm 0.09 \\
3.98 \pm 0.15\end{array}$} & \multicolumn{3}{|c|}{ Arterial Potassium $(\mu \mathbf{M} / \mathbf{m l})$} & \multirow{3}{*}{$\begin{array}{l}3.89 \pm 0.07 \\
3.82 \pm 0.19\end{array}$} & \multirow{3}{*}{$\begin{array}{l}3.90 \pm 0.09 \\
3.50 \pm 0.14\end{array}$} \\
\hline & & & $4.06 \pm 0.08$ & $3.94 \pm 0.09$ & $4.07 \pm 0.10$ & & \\
\hline & & & $3.82 \pm 0.26$ & $3.88 \pm 0.23$ & $3.83 \pm 0.23$ & & \\
\hline \multirow{3}{*}{$\begin{array}{l}\text { C } \\
\mathrm{D}\end{array}$} & & & \multicolumn{3}{|c|}{ Arteriovenous Potassium Difference $(\mu \mathbf{M} / \mathbf{m l})$} & \multirow{3}{*}{$\begin{array}{l}+0.05 \pm .02 \\
+0.02 \pm .07\end{array}$} & \multirow{3}{*}{$\begin{array}{l}+0.04 \pm .02 \\
+0.08 \pm .06\end{array}$} \\
\hline & $-0.23 \pm .13$ & $-0.07 \pm .11$ & $-0.24 \pm .08$ & $-0.28 \pm .04$ & $-0.17 \pm .04$ & & \\
\hline & $-0.12 \pm .06$ & $-0.04 \pm .10$ & $-0.05 \pm .13$ & $-0.08 \pm .09$ & $-0.05 \pm .04$ & & \\
\hline \multirow{3}{*}{$\begin{array}{l}\text { C } \\
\text { D }\end{array}$} & & & \multicolumn{3}{|c|}{ Arterial Calcium $(\mu \mathrm{M} / \mathrm{ml})$} & \multirow{3}{*}{$\begin{array}{l}4.45 \pm .19 \\
4.17 \pm .13\end{array}$} & \multirow{3}{*}{$\begin{array}{l}4.18 \pm .05 \\
4.06 \pm .19\end{array}$} \\
\hline & $4.22 \pm .08$ & $4.14 \pm .13$ & $4.33 \pm .08$ & $4.31 \pm .02$ & $4.22 \pm .09$ & & \\
\hline & $4.14 \pm .12$ & $4.32 \pm .08$ & $4.20 \pm .13$ & $4.33 \pm .12$ & $4.08 \pm .13$ & & \\
\hline \multirow{3}{*}{$\begin{array}{l}\text { C } \\
\text { D }\end{array}$} & & & \multicolumn{3}{|c|}{ Arteriovenous Calcium Differences $(\mu \mathbf{M} / \mathbf{m l})$} & & \\
\hline & $-0.03 \pm .13$ & $-0.09 \pm .05$ & $+0.03 \pm .06$ & $-0.14 \pm .10$ & $-0.02 \pm .06$ & $+0.19 \pm .16$ & $+0.08 \pm .06$ \\
\hline & $+0.01 \pm .06$ & $+0.10 \pm .07$ & $+0.14 \pm .06$ & $+0.25 \pm .15$ & $-0.01 \pm .07$ & $+0.21 \pm .02$ & $+0.13 \pm .03$ \\
\hline
\end{tabular}

Results are expressed as means \pm standard error of the mean.

Statistical analysis of data showed no difference between controls and patients

assuming that all of the glucose (lactate was subtracted) was metabolized to $\mathrm{CO}_{2}$ and water. In the normals this was $28 \pm 10 \%$ at rest, $17.6 \pm 5.7$ during exercise, and 50.2 \pm 15 during recovery. These are similar to previously reported data (Baltzan et al, 1962). In denervated patients the comparable values were $24.8 \pm 5.6 \%$ at rest, $36 \pm 20$ during exercise, and $17 \pm 9$ during recovery.

\section{Lactate (Table 5)}

Arterial lactate was constant during the period of observation in both groups, but was significantly higher in patients with chronic denervation. Arteriovenous differences changed little from rest to exercise but, because of significantly wider arteriovenous differences of lactate at rest $(p<.02)$ and during exercise $(p<.05)$ in the patients, the quantity of lactate released from forearm tissues was greater than in controls $(p<.01)$. The hyperlactatemia observed in denervated patients appears to be a consequence of increased lactate production by skeletal muscle.

\section{Oleic Acid (Table 5)}

Arterial oleic acid levels were within the normal range in both groups. In several instances we were not able to measure oleic acid levels because of inadequate quantities of plasma. The arterial levels did not change during the study. Arteriovenous differences were slightly positive at rest, and varied from positive to negative during exercise and recovery. This reflects the net effects of uptake by skeletal muscle and output from the adipose tissue, which did not appear to be increased in the denervated muscles.

In addition to the determination of oleic acid in blood, we also measured the tissue uptake of 14-C oleic acid bound to albumin as a specific marker of influx of oleic acid to muscle. In control subjects extraction was constant during rest, exercise, and recovery and averaged about $1 / 3$ of the input. Patients with denervation also had a constant extraction but it was slightly greater; about 1/2 of the label being extracted. These observations confirm the RQ data which suggested that a major portion of the oxidative needs of forearm tissues was met by fatty acid oxidation.

\section{MUSCLE HISTOPATHOLOGY AND HISTOCHEMISTRY (FIGURE 2)}

All biopsies were taken from the biceps brachii. The specimens showed the typical pattern of denervation atrophy (Dorman, 1973; Dubowitz and Brooke, 1973). There were numerous atrophic fibers which appeared to have angular shape on

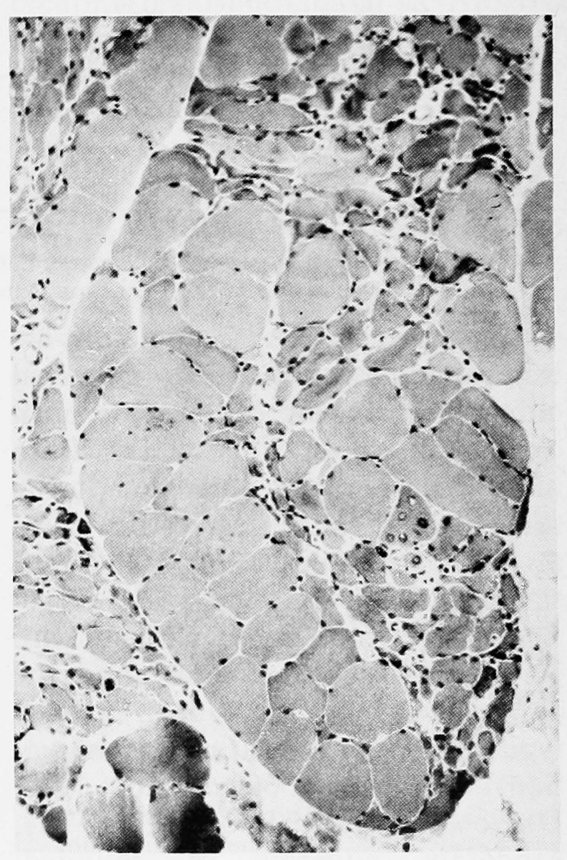

Fig. 2-Biopsy of biceps brachii muscle from patient 2. A fascicle is composed of grouped atrophic (denervated) muscle fibers as well as areas of normal sized or hypertrophic muscle fibers. Cryostat section, modified trichrome stain, magnification is $\mathrm{x} 140$. 
TABLE 5

Arterial concentrations and arteriovenous gradients of glucose, lactate and oleate at rest, during exercise, and recovery' in controls (C) and patients (D)

\begin{tabular}{|c|c|c|c|c|c|c|c|}
\hline & \multicolumn{2}{|c|}{ Rest } & \multicolumn{3}{|c|}{ Exercise } & \multicolumn{2}{|c|}{ Recovery } \\
\hline $\begin{array}{l}\text { C } \\
\text { D }\end{array}$ & $\begin{array}{l}5.50 \pm .27 \\
5.00 \pm .03\end{array}$ & $\begin{array}{l}5.43 \pm .24 \\
5.03 \pm .08\end{array}$ & $\begin{array}{l}5.48 \pm .28 \\
5.00 \pm .09\end{array}$ & $\begin{array}{l}5.41 \pm .22 \\
5.03 \pm .09\end{array}$ & $\begin{array}{l}5.42 \pm .23 \\
5.07 \pm .09\end{array}$ & $\begin{array}{l}5.48 \pm .24 \\
5.10 \pm .14\end{array}$ & $\begin{array}{l}5.54 \pm .24 \\
5.04 \pm .17\end{array}$ \\
\hline $\begin{array}{l}\text { C } \\
\text { D }\end{array}$ & $\begin{array}{l}0.12 \pm .05 \\
0.23 \pm .05\end{array}$ & $\begin{array}{l}0.13 \pm .02 \\
0.22 \pm .05\end{array}$ & $\begin{array}{l}\text { Arteriove } \\
0.18 \pm .10 \\
0.27 \pm .13\end{array}$ & $\begin{array}{c}\text { Glucose Diffe } \\
0.13 \pm .03 \\
0.21 \pm .08\end{array}$ & $\begin{array}{c}(\mu \mathbf{M} / \mathbf{m l}) \\
0.15 \pm .02 \\
0.30 \pm .08\end{array}$ & $\begin{array}{l}0.23 \pm .04 \\
0.23 \pm .06\end{array}$ & $\begin{array}{l}0.16 \pm .05 \\
0.10 \pm .05\end{array}$ \\
\hline $\begin{array}{l}\text { C } \\
\text { D }\end{array}$ & $\begin{array}{r}0.40 \pm .03 \\
1.29 \pm .24 \\
\mathrm{p}<.01\end{array}$ & $\begin{array}{r}0.41 \pm .04 \\
1.25 \pm .25 \\
\mathrm{p}<.01\end{array}$ & $\begin{array}{r}\quad \\
0.46 \pm .04 \\
1.23 \pm .27 \\
\mathrm{p}<.02\end{array}$ & $\begin{array}{c}\text { al Lactate }(\mu) \\
0.41 \pm .06 \\
1.19 \pm .28 \\
\mathrm{p}<.02\end{array}$ & I) $\begin{array}{r}0.46 \pm .04 \\
1.34 \pm .30 \\
\mathrm{p}<.02\end{array}$ & $\begin{array}{r}0.48 \pm .05 \\
1.41 \pm .29 \\
p<.02\end{array}$ & $\begin{array}{l}0.45 \pm .05 \\
1.38 \pm .35 \\
\pm .01\end{array}$ \\
\hline $\begin{array}{l}\text { C } \\
\text { D }\end{array}$ & $\begin{array}{r}-0.04 \pm .06 \\
-0.33 \pm .08 \\
p<.02\end{array}$ & $\begin{array}{r}-0.05 \pm .04 \\
-.024 \pm .05 \\
p<.05\end{array}$ & $\begin{array}{c}\text { Arteriover } \\
-0.04 \pm .03 \\
-0.23 \pm .05 \\
\mathrm{p}<.05\end{array}$ & $\begin{array}{c}\text { Lactate Diffe } \\
-0.05 \pm .02 \\
-0.34 \pm .10 \\
p<.05\end{array}$ & $\begin{array}{r}\mathbf{s}(\mu \mathbf{M} / \mathrm{ml}) \\
-0.05 \pm .04 \\
-0.36 \pm .11 \\
\mathrm{p}<.05\end{array}$ & $\begin{array}{r}-0.04 \pm .03 \\
-0.22 \pm .04 \\
p<.05\end{array}$ & $\begin{array}{r}-0.06 \pm .03 \\
-0.27 \pm .11 \\
p<.05\end{array}$ \\
\hline $\begin{array}{l}\text { C } \\
\text { D }\end{array}$ & $\begin{array}{l}0.269 \\
0.204 \pm .039\end{array}$ & $\begin{array}{l}0.280 \\
0.220 \pm .045\end{array}$ & $\begin{array}{l}\text { Ar } \\
0.270 \\
0.174 \pm .021\end{array}$ & $\begin{array}{l}\text { Oleic Acid } \\
0.283 \\
0.206 \pm .034\end{array}$ & $\begin{array}{l}\mathrm{ml}) \\
0.314 \\
0.218 \pm .037\end{array}$ & $\begin{array}{l}0.290 \\
0.216 \pm .035\end{array}$ & $0.197 \pm .030$ \\
\hline $\begin{array}{l}\text { C } \\
\text { D }\end{array}$ & $\begin{array}{l}+.027 \\
+.031 \pm .010\end{array}$ & $\begin{array}{l}+.039 \\
+.033 \pm .035\end{array}$ & $\begin{array}{l}\text { Arterioven } \\
+.016 \\
-.012 \pm .017\end{array}$ & $\begin{array}{l}\text { leic Acid Dif } \\
+.033 \\
+.017 \pm .013\end{array}$ & $\begin{array}{l}\text { ce }(\mu \mathbf{M} / \mathrm{ml}) \\
-.019 \\
+.009 \pm .026\end{array}$ & $\begin{array}{l}-.052 \\
+.038 \pm .013\end{array}$ & $\begin{array}{l}-.009 \\
+.002 \pm .006\end{array}$ \\
\hline $\begin{array}{l}\text { C } \\
\text { D }\end{array}$ & $\begin{array}{l}48.1 \pm 8.6 \\
56.7 \pm 6.2\end{array}$ & $\begin{array}{l}34.9 \pm 11.6 \\
61.2 \pm 8.4\end{array}$ & $\begin{array}{r}\text { Perce } \\
30.6 \pm 9.7 \\
47.0 \pm 6.0\end{array}$ & $\begin{array}{c}\text { traction } 14-\mathrm{C} \\
36.0 \pm 9.3 \\
51.1 \pm 4.2\end{array}$ & $\begin{array}{l}\text { Acid } \\
35.5 \pm 4.7 \\
46.9\end{array}$ & $\begin{array}{c}27.5 \pm 5.1 \\
42.8 \pm 18.2\end{array}$ & $\begin{array}{l}36.8 \pm 7.9 \\
63.9 \pm 9.6\end{array}$ \\
\hline
\end{tabular}

Results are expressed as means \pm standard error of the mean

Statistical analysis of data revealed significant difference only where the $p$ values are indicated.

transverse view. These fibers occurred either in a random distribution or in clusters of about 20-60 fibers. Both histochemical types atrophied to the same extent and degree. In most atrophic fibers, periodic acid Schiff stainable glycogen was lost. Target fibers were rare. In the patients with peroneal muscular atrophy and the chronic lower motor neuron disease, type grouping indicating reinnervation was present (Dorman, 1973; Dubowitz and Brooke, 1973). Moderate numbers of rounded, hypertrophic fibers were present in all biopsies.

\section{DISCUSSION}

The results of the forearm metabolic study during a standard exercise regime may be expressed as per unit volume of forearm or per unit work performed. We have chosen the former reference basis for the following reasons: a) a comparison to the resting state can thus be made (when only the forearm volume reference basis can be used) b) the nonexercising, denervated muscle tissue can also be included in this reference basis c) precise measurements of the work of the exercising forearm is difficult and d) in previous studies the forearm volume reference basis has been utilized (Zierler et al, 1968; Klassen et al, 1970 and Baltzan et al, 1962, 1965). We think that as long as the duration and the circumstances of the exercise were identical in the control and patient groups, the results expressed per unit volume of forearm are valid for statistical comparisons between the two groups.

At rest, human skeletal muscles use virtually no blood borne fuels and utilize mainly intrafiber energy sources, i.e. glycogen for glycolysis and neutral lipid for fatty acid (FA) oxidation (Felig and Wahren, 1975; Hultman, 1967). It is surmised that histochemical type IIB fibers utilize mainly glycogen while type I fibers use predominantly FA, and type IIA fibers are capable of metabolizing both fuels equally well.

In denervated muscle fibers, glycogen is rapidly lost (Dorman, 1973) and in our experience lipid droplets also become scanty, which must impose an altered form of fuel hemostasis on denervated muscle cells. 
We have found that there was an obvious trend to increased glucose and fatty acid extraction from arterial blood in denervated forearms, presumably to compensate for the loss of "intrinsic" fuels in denervated muscle fibers. In addition, there was a significant increase of oxygen utilization at rest, but the portion of $\mathrm{O}_{2}$ utilized for glycolysis was not increased, which implies that a) the increased $\mathrm{O}_{2}$ uptake was mainly utilized for fatty acid oxidation and b) some of the increased glucose taken up by muscle was metabolized anaerobically. This latter supposition was strengthened by the fact that an increased lactate output from muscle was demonstrated, which presumably contributed to the systemic hyperlactatemia. [We can probably rule out an impaired lactate uptake by liver and/or heart as the cause of hyperlactatemia which is known to occur after ethanol intake (Chui et al, 1968)].

During exercise in normal muscles the blood-born fuels, i.e. fatty acids and glucose, constitute the major sources of fuels (Hagenfeld and Wharen, 1971) while "intrinsic" fuels become negligible factors. In denervated forearms, the increase of glucose and fatty acid extraction by muscle was comparable to controls, but the relative increase of $\mathrm{O}_{2}$ uptake was less and lactate output was considerably greater than in normal exercising muscle. This again suggested that fatty acid utilization was not impaired and that a higher than normal proportion of the glucose was metabolized anaerobically.

These results pose several questions. Since in the diseased forearm muscles there are both denervated and innervated muscle fibers, which of these are mainly responsible for the augmented anaerobic glycolysis? (It is assumed that the metabolic responses in our studies were primarily determined by skeletal muscles rather than other tissues of the forearm). There appeared to be no preferential atrophy of the aerobic (type I) fibers in any of these patients' muscle biopsies to suggest that there was an increased relative proportion of anaerobic, glycolytic fibers which could have switched the entire muscle towards anaerobic metabolism.

We should like to propose three possible explanations to account for the high lactate generation and output by skeletal muscles:

1) In denervated muscles, there may be relative muscle ischemia. This proposition may appear paradoxical in view of the fact that in denervated muscles the capillary density surrounding most muscle fibers is adequate or even relatively increased and there is no structural abnormality of capillaries (Carpenter et al, 1976). It is also apparent from our data, considering venous $\mathrm{p}_{2}$, that adequate overall reserves of oxygen were still present in the venous blood. Therefore, if ischemia were the cause, it could only be a regional phenomenon. This, in turn, could be caused by a defective autoregulation of regional blood flow. As a result some areas (probably the denervated and thus non-contracting fibers) may receive "luxury" perfusion while other, active regions could be relatively deprived of adequate blood supply. [Luxury perfusion of denervated (atrophic) fibers may occur because the capillary density does not immediately decrease around atrophic fibers (Carpenter et al, 1976)]. Active spatial and temporal regional variation of blood flow is known to occur in normal skeletal muscles (Johnson and Wayland, 1967; Paradise et al, 1971; Folkow and Halicka, 1968; and Renkin, 1967). A denervating process may offset autoregulation either by direct interference with the normal regulation of blood vessel lumens or indirectly by reducing the amount or pattern of muscle activity upon which autoregulation ultimately rests.

2) A second possible mechanism to explain the lactate findings may be an increased reactivity of blood vessels to circulating catecholamines. This may be supported by the fact that similar abnormalities have been observed during artificially induced increased catecholamine concentration in circulating blood (Baltzan et al, 1965). Furthermore, in blood vessels of denervated skeletal muscles, there is a markedly increased concentration of $\beta$-adrenergic receptors (Reddy and Engel, 1978). Impressive alteration of cyclic nucleotidase activity in denervated muscles was also shown by Novom and Lewinstein (1977), which implies altered responsiveness of the muscle cells and blood vessels or both to catecholamines and possibly to other hormonal influences that may have a role in the autoregulation of muscle blood flow.

3) A third possible mechanism which could attribute to the relative or regional ischemia may arise as a result of excessively hypertrophic fibers, around which capillarization has not become proportionate to the increase of the muscle fiber size. Such muscle fibers have been quite numerous in our biopsies. In these muscle cells, the most central portions of the cytoplasm may be relatively deprived of oxygen and diffusable metabolic fuels because of increased distance between the sources of the fuels (capillaries) and the site of metabolism. Occasionally, such hypertrophic cells are known to become necrotic, presumably as a result of a metabolic "bankruptcy" based on the proposed mechanism.

The elevated arterial and venous creatine phosphokinase activity is interesting since it is generally believed that in denervating diseases the activity of this enzyme does not increase at all, or only slightly. Since the precise molecular mechanism which controls the efflux of this enzyme from the muscle cell into the extracellular space is undetermined, we could not identify the causes which gave rise to the increased activity of this enzyme in blood in our patients.

\section{REFERENCES}

ANDRES, R., LADER, G., GOLDMAN, P. and ZIERLER, K. L. (1957). Net potassium movement between resting muscle and plasma in man in the basal state and during the night. J. Clin. Invest. 36, 723-729.

ANDRES, R., ZIERLER, K. L., ANDERSON, M. H., STAINSKY, W. M., LADER, G., LTHRAYYIK, S. and LILIENTHAL, J. L. (1954). Measurement of blood flow and volume in the forearm of man, with notes on theory of indicator-dilution and on production of turbulence hemolysis and vasodilatation by intra-vascular injection. $J$. Clin. Invest. 33, 482-504.

BALTZAN, M. A., ANDRES, R., LADER, G. and ZIERLER, K. L. (1962). Heterogeneity of forearm metabolism with special reference to free fatty acids. J. Clin. Invest. $41,116-125$. 
BALTZAN, M. A., ANDRES, R., LADER, G. and ZIERLER, K. L. (1965). Effects of epinephrine on forearm blood flow and metabolism in man. J. Clin. Invest. $44,80-$ 92.

CARPENTER, S., KARPATI, G., ROTHMAN, S. and WATTERS, G. (1976). The childhood type of dermatomyositis. Neurology (Minneap.) 26, 952-962.

CHUI, L. A., MUNSAT, T. L. and CRAIG, J. R. (1978). Effect of ethanol on lactic acid production by exercised normal muscle. Muscle and Nerve 1, 57-61.

DORMAN, J. (1973). Histopathology of neurogenic muscular atrophy. In The Striated Muscle. eds. C. M. Pearson and F. K. Mostofi, pp. 249-262. The Williams and Wilkins Company, Baltimore.

DUBOWITZ, V. and BROOKE, M. H. (1973). Muscle Biopsy: A Modern Approach. W. B. Saunders and Company, London, Philadelphia, Toronto, 5-33.

DUBOWITZ, V. and BROOKE, M. H. (1973). Muscle Biopsy: A Modern Approach. W. B. Saunders and Company, London, Philadelphia, Toronto, 105-167.

FELIG, P. and WAHREN, J. (1975). Fuel homeostasis in exercise. New England Journal of Medicine, 293, 1078-1084.

FOLKOW, B. and HALICKA, H. D. (1968). A comparison between "red" and "white" muscle with respect to blood supply, capillary surface area and oxygen uptake during rest and exercise. Microvasc. Res. I, $1-14$.
HAGENFELDT, L. and WAHREN, J. (1971). Metabolism of free fatty acids and ketone bodies in skeletal muscle. In Muscle Metabolism During Exercise. eds. B. Pernow and B. Saltin, pp. 153-163. New York, Plenum Press.

HORN, H. D. and BRUNS, F. P. (1956). Quantitative Bestimmung von $L$ ( $t$ )Milchsaure mit Milchsaure-dehydrogenase. Biochim. Biophys. Acta. (Amst.) 21, 378380.

HULTMAN, E. (1967). Studies on muscle metabolism of glycogen and active phosphate in man with special reference to exercise and diet. Scand. J. Clin. Lab. Invest. 19, Suppl. 94, 1-63.

JOHNSON, P. C. and WAYLAND, H. (1967). Regulation of blood flow in single capillaries. Am. J. Physiol. 212, 1405-1415.

KLASSEN, G. A. (1974). Measurement of long chain fatty acids. In Application of Gas Chromatography - Mass Spectrometry to the Investigation of Human Disease. eds. $O$. A. Mamer, W. J. Mitchell and L. R. Scriver, pp. 119-122. The McGill University Montreal Childrens Research Institute.

KLASSEN, G. A., ANDREW, G. M. and BECKLAKE, M. R. (1970). Effect of training on total and regional blood flow and metabolism in paddlers. J. Appl. Physiol. 28, 397-406.

KLASSEN, G. A., ARONOFF, A. and KARPATI, G. (1969). Forearm metabolism in patients with chronic liver disease. Clin. Sci. $37,455-470$.

KUBY, S. A., NADA, L. and LARDY, H. A. (1954). Adenosine triphosphate-creatine transphosphorylase. J. Biol. Chem. 210, 6582.
McCANN, W. P. and JUDE, J. R. (1958). The synthesis of glucose by the kidney. Bull Johns Hopkins Hosp. 103, 77-93.

NOVOM, S. and LEWINSTEIN, S. (1977). Adenylic cyclase and guanylate cyclase of normal and denervated skeletal muscle. Neurology 27, 869-874.

PARADISE, N. F., SWAYZE, C. R., SHIN, D. H. and FOX, I. J. (1971). Perfusion heterogeneity in skeletal muscle using tritiated water. Am. J. Physiol. 220, 1107 1115.

REDDY, N. B. and ENGEL, W. K. (1978). Differential effects of denervation on skeletal muscle adenylate cyclase $(\mathrm{AC})$ and $\beta$ adrenergic receptor binding. Neurology 28 , 399-400.

RENKIN, E. M. (1959). Transport of potassium-42 from blood to tissue in isolated skeletal muscle. Am. J. Physiol. 197, 1205 1210.

SNEDECOR, G. W. and COCHRAN, W. G. (1967). Statistical Methods 6th Ed. Iowa State Univ. Press, Iowa, USA.

STONNINGTON, H. H. and ENGEL, A. G. (1973). Normal and denervated muscle. A morphometric study of fine structure. Neurology (Minneap.) 23, 714-724.

VAN SLYKE, D. D. and NEILL, J. M. (1924). The determination of gases in blood and other solutions by vacuum extraction and manometric measurement. J. Biol. Chem. 61, 527-573.

ZIERLER, K. L., MASERI, A., KLASSEN, G., RABINOWITZ, D. and BURGESS, J. (1968). Muscle metabolism during exercise in man. Trans. Assoc. of Am. Phys. 81, 266-272. 